Check for updates

Cite this: RSC Adv., 2018, 8, 39177

\title{
Tuning of spinel magnesium ferrite nanoparticles with enhanced magnetic properties $\uparrow$
}

\author{
Liyun Zheng, (D) *ab Kan Fang, ${ }^{a}$ Meiling Zhang, ${ }^{b}$ Zhixian Nan, ${ }^{a}$ Lixin Zhao, ${ }^{* c}$ \\ Dong Zhou, Minggang Zhu ${ }^{\mathrm{b}}$ and Wei Lib
}

Monodispersed magnesium ferrite nanoparticles with enhanced magnetic properties were successfully fabricated by a simple solvothermal method without employing any templates, complex apparatus or techniques. The structure, morphology, composition, and magnetic properties of the products were tuned and characterized by X-ray powder diffraction, transmission electron microscopy, scanning electron microscopy and vibrating sample magnetometry. The results show that the reaction time and temperature have an important influence on the morphology, composition, structure and particle size of the synthesized $\mathrm{MgFe}_{2} \mathrm{O}_{4}$ nanoparticles. Not only the size, size distribution, crystallization, but also the atomic ratio of $\mathrm{Mg}$ : Fe has a decisive effect on their magnetic properties. The $\mathrm{MgFe}_{2} \mathrm{O}_{4}$ magnetic nanoparticles synthesized at $180{ }^{\circ} \mathrm{C}$ for 12 hours have excellent dispersion, narrow size distribution, good crystallinity and a $\mathrm{Mg}$ : Fe atomic ratio of approximately $1: 4.53$ and an average particle size of $114.3 \mathrm{~nm}$, thus the highest saturation magnetization of $67.35 \mathrm{emu} \mathrm{g}^{-1}$. It provides a reliable synthesis method for the better application of spinel structure magnesium ferrite nanoparticles in the future.

Received 7th September 2018 Accepted 15th November 2018

DOI: $10.1039 / c 8 r a 07487 a$

rsc.li/rsc-advances
For $\mathrm{MgFe}_{2} \mathrm{O}_{4}$ nanoparticles, there are many works focused on its nanostructures and properties. Huang et al. ${ }^{15}$ synthesized $\mathrm{MgFe}_{2} \mathrm{O}_{4}$ nanocrystallites with a particle size of about $10 \mathrm{~nm}$ and a saturation magnetization of $30.6 \mathrm{emu}^{-1} \mathrm{using}$ a sol-gel/combustion method. But the nanoparticles were aggregated after combustion. Shen et al. ${ }^{16}$ synthesized $\mathrm{MgFe}_{2} \mathrm{O}_{4}$ nanospheres with a diameter of about $370 \mathrm{~nm}$ by one-pot solvothermal method. Sivakumar et al. ${ }^{17}$ obtained nanocrystalline $\mathrm{MgFe}_{2} \mathrm{O}_{4}$ with grain size of $19-72 \mathrm{~nm}$ and particle size of 220-340 nm using ceramic method plus mechanical milling. The sample with a grain size of $72 \mathrm{~nm}$ got the highest saturation magnetization of $36 \mathrm{emu} \mathrm{g}^{-1}$ at $293 \mathrm{~K}$. Šepelák et $a l^{18}$ used one-step mechanochemical route and obtained nanocrystalline $\mathrm{MgFe}_{2} \mathrm{O}_{4}$ with a saturation magnetisation of $50 \mathrm{emu}^{-1}$. They found that the high-energy milling process leads to the decrease of the fraction of iron cations on tetrahedral sites from $x \sim 0.9$ (for bulk sample) to $x \sim 0.76$, inducing redistribution of cations between tetrahedral and octahedral sites. In addition, they also found that the milled $\mathrm{MgFe}_{2} \mathrm{O}_{4}$ is magnetically disordered due to spin canting. Durrani et al. ${ }^{19}$ synthesized crystalline magnesium ferrite spinel oxide powders by nitrate-citrate sol-gel autocombustion process. They found that the calcined powder had an optical band gap of $2.17 \mathrm{eV}$. Hankare et al. ${ }^{20}$ prepared polycrystalline magnesium ferrite by co-precipitation method and measured its gas-sensation. They found that the $\mathrm{MgFe}_{2} \mathrm{O}_{4}$ based sensor exhibited a fast response and a good recovery towards petrol at $250{ }^{\circ} \mathrm{C}$. Chen et al. ${ }^{21}$ used ultrasonic waveassisted ball milling with magnesium carbonate and iron

$\dagger$ Electronic supplementary information (ESI) available. See DOI:

$10.1039 / \mathrm{c} 8 \mathrm{ra} 07487 \mathrm{a}$

${ }^{a}$ College of Materials Science and Engineering, Hebei University of Engineering, Handan, 056038 China. E-mail: zhengliyun@126.com

${ }^{b}$ Division of Functional Materials, Central Iron \& Steel Research Institute, 76 Xueyuan South Road, Beijing 100081, China. E-mail: weili@cisri.com.cn

${ }^{c}$ College of Mechanical and Equipment Engineering, Hebei University of Engineering, 199 Guangming South Street, Handan 056038, Hebei, China. E-mail: zhaolx1120@ 126. com 
oxide and directly synthesized nano-sized $\mathrm{MgFe}_{2} \mathrm{O}_{4}$ that got a saturation magnetization of $54.84 \mathrm{emu}^{-1}$.

But up to date, there is less report about the relationship between the composition, process and properties that is very important for its applications..$^{22}$ In the present paper, single phase, spinel magnesium ferrite nanoparticles were prepared by a simple solvothermal synthesis method. Particularly, it is worth to point out that changing the solvothermal reaction temperature and time will greatly affect the structure, composition and thus the magnetic properties of the obtained spinel magnesium ferrite nanoparticles. The properties of the synthesized magnesium ferrite nanoparticles have strong dependence on their morphology, composition and structure. This work will play a greater role in the wider application in the future.

\section{Experimental}

Spinel magnesium ferrite nanoparticles have been synthesized by the following method. $\mathrm{FeCl}_{3} \cdot 6 \mathrm{H}_{2} \mathrm{O}(1.35 \mathrm{~g}, 5 \mathrm{mmol})$, $\mathrm{MgCl}_{2} \cdot 6 \mathrm{H}_{2} \mathrm{O}(0.51 \mathrm{~g}, 0.25 \mathrm{mmol})$ and $0.02 \mathrm{~g}$ polyvinyl pyrrolidone (PVP) were dissolved in ethylene glycol $(50 \mathrm{~mL})$ until a homogeneous solution was formed. Then $3.20 \mathrm{~g} \mathrm{NaOH}$ were added slowly into the above solution under strongly agitation. The mixture was stirred vigorously for $60 \mathrm{~min}$ and then sealed in a Teflon-lined stainless-steel autoclave. The autoclave was heated to different temperatures $\left(160{ }^{\circ} \mathrm{C}, 180{ }^{\circ} \mathrm{C}, 200{ }^{\circ} \mathrm{C}\right)$, maintained for $3 \mathrm{~h}, 6 \mathrm{~h}, 12 \mathrm{~h}$ and cooled to room temperature. The black products were separated with a magnet and washed three times with absolute deionized water and ethanol. The resulting magnetic materials were then dried at $80{ }^{\circ} \mathrm{C}$ for $6 \mathrm{~h}$.

The structure of $\mathrm{MgFe}_{2} \mathrm{O}_{4}$ powders was determined by X-ray diffractometer (XRD). The morphology and microstructure of $\mathrm{MgFe}_{2} \mathrm{O}_{4}$ nanoparticles were observed by transmission electron microscopy (TEM) and high resolution TEM (HRTEM) using a JEOL 2100 transmission electron microscope. The TEM samples were made by placing a drop of powder solution on a carbon-coated copper grid. Scanning electron microscopy (SEM) was used to perform EDS composition analysis. Magnetic properties were measured by vibrating sample magnetometer (VSM).

\section{Results and discussion}

The preparation procedure of $\mathrm{MgFe}_{2} \mathrm{O}_{4}$ nanoparticles, a solvothermal synthesis method, is shown in Fig. 1. This biocompatible polymer of PVP is regarded as an ideal candidate for

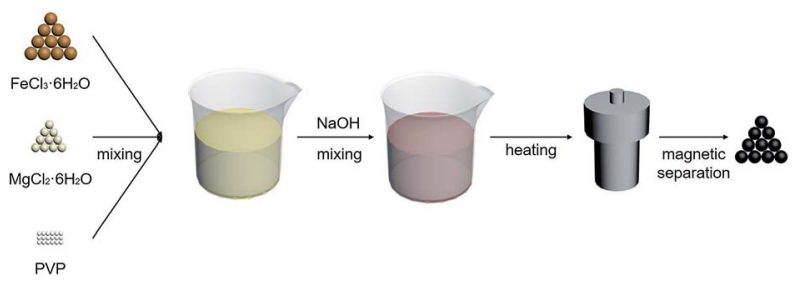

Fig. 1 Schematic illustration of the synthesis process of $\mathrm{MgFe}_{2} \mathrm{O}_{4}$ nanoparticles.

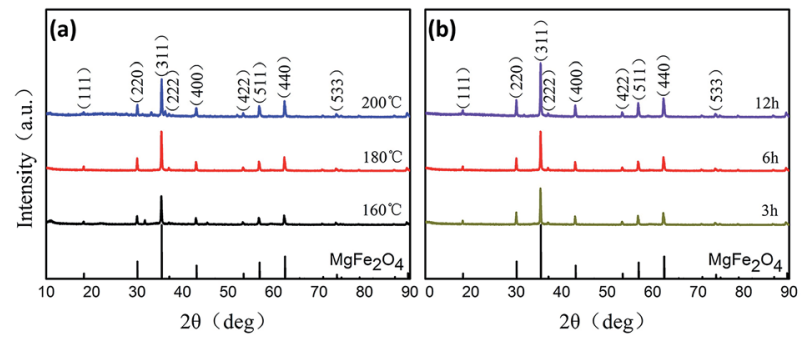

Fig. 2 XRD patterns of $\mathrm{MgFe}_{2} \mathrm{O}_{4}$ magnetic nanoparticles synthesized at (a) different temperatures for $6 \mathrm{~h}$, (b) $180^{\circ} \mathrm{C}$ for different times.

surface modification of nanoparticles, which is benefit for $\mathrm{MgFe}_{2} \mathrm{O}_{4}$ nanoparticles to deal with the dispersion and biocompatibility problems. ${ }^{23}$ As $\mathrm{NaOH}$ solution was added into the mixing salt solution, the color changed rapidly from initially yellow to dark black. In our work, we firstly tried to stabilize the reaction time as $6 \mathrm{~h}$, and synthesized $\mathrm{MgFe}_{2} \mathrm{O}_{4}$ by changing the reaction temperature as $160^{\circ} \mathrm{C}, 180^{\circ} \mathrm{C}$ and $200^{\circ} \mathrm{C}$, respectively. After that, $180^{\circ} \mathrm{C}$ was selected as the fixed reaction temperature, and $\mathrm{MgFe}_{2} \mathrm{O}_{4}$ was synthesized by changing the reaction time as $3 \mathrm{~h}, 6 \mathrm{~h}$ and $12 \mathrm{~h}$, respectively.

The crystalline structure of the $\mathrm{MgFe}_{2} \mathrm{O}_{4}$ nanoparticles functionalized with PVP was determined by XRD and HRTEM. As shown in Fig. 2, it is found that the d-spacing values of significant diffraction peaks match well with data from the JCPDS card (88-1942) for $\mathrm{MgFe}_{2} \mathrm{O}_{4}$. The characteristic peaks at $2 \theta$ of $18.28,30.07,35.41,37.04,43.04,53.39,56.91,62.50$ and 73.93 are corresponding to (111), (220), (311), (222), (400), (422), (511), (440), and (533) crystallographic planes of spinel phase, respectively. Only the sample synthesized at $200{ }^{\circ} \mathrm{C}$ for $6 \mathrm{~h}$ has some impurities like $\mathrm{Fe}_{2} \mathrm{O}_{3}$ or $\mathrm{FeO}$, showing small peaks at 33.06 and 36.04 degrees. For other samples, except some remaining $\mathrm{NaCl}$, no other crystalline impurities are detected. In addition, as shown in Fig. 2a, the intensities of the diffraction peaks of the samples increase with increasing synthesizing temperature when the reaction time is $6 \mathrm{~h}$. On the other hand, at the same reaction temperature, the intensities of the diffraction peaks of the samples increase with reaction time (shown in Fig. 2b). This indicates that the reaction temperature and time have some effect on the synthesis of $\mathrm{MgFe}_{2} \mathrm{O}_{4}$ magnetic nanoparticles. The lowest peak intensity of $\mathrm{MgFe}_{2} \mathrm{O}_{4}$ nanoparticles synthesized at $160{ }^{\circ} \mathrm{C}$ for $6 \mathrm{~h}$ indicates that the crystallinity of the $\mathrm{MgFe}_{2} \mathrm{O}_{4}$ nanoparticles may be relatively poor. The peak intensity of $\mathrm{MgFe}_{2} \mathrm{O}_{4}$ nanoparticles synthesized at $180{ }^{\circ} \mathrm{C}$ for $12 \mathrm{~h}$ indicates that the sample has good crystallinity, which is the best synthesis condition of $\mathrm{MgFe}_{2} \mathrm{O}_{4}$ magnetic nanoparticles in this work. We have obtained the crystallite sizes from the XRD data through Rietveld refinement (shown in Table 1).

From HRTEM (shown in ESI Fig. S1 $\dagger$ ), we find that all the $\mathrm{MgFe}_{2} \mathrm{O}_{4}$ samples synthesized in the work are single-crystal nanoparticles. TEM images and size distributions of the PVPtreated $\mathrm{MgFe}_{2} \mathrm{O}_{4}$ magnetic nanoparticles synthesized under different conditions are shown in Fig. 3. From Fig. 3 left column, it can be clearly observed that all the synthesized nanoparticles have good and cuboid shape. The particle size 
Table 1 The average particle size, atomic ratio of $\mathrm{Mg}$ and $\mathrm{Fe}$ and saturation magnetizations of the $\mathrm{MgFe}_{2} \mathrm{O}_{4}$ nanoparticles synthesized under different reaction conditions

\begin{tabular}{|c|c|c|c|c|}
\hline $160^{\circ} \mathrm{C}, 6 \mathrm{~h}$ & 114.4 & 76.4 & $1: 5.05$ & 51.8 \\
\hline $200{ }^{\circ} \mathrm{C}, 6 \mathrm{~h}$ & 159.9 & 62.6 & $1: 3.69$ & 60.2 \\
\hline $180^{\circ} \mathrm{C}, 3 \mathrm{~h}$ & 111.8 & 82.5 & $1: 2.34$ & 41.3 \\
\hline $180^{\circ} \mathrm{C}, 12 \mathrm{~h}$ & 114.3 & 66.7 & $1: 4.53$ & 67.4 \\
\hline
\end{tabular}

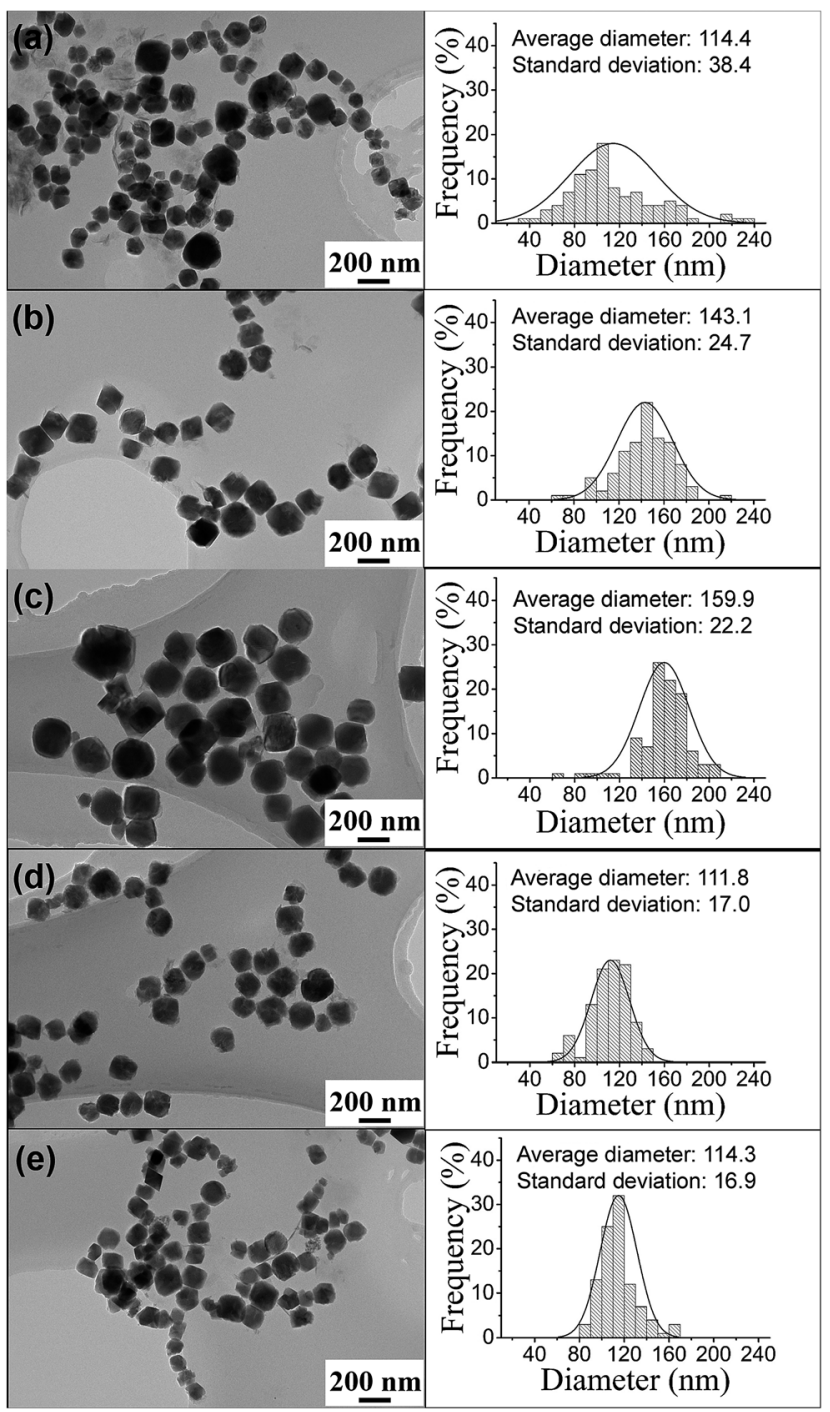

Fig. 3 TEM images of $\mathrm{MgFe}_{2} \mathrm{O}_{4}$ magnetic nanoparticles synthesized at (a) $160{ }^{\circ} \mathrm{C}$, (b) $180{ }^{\circ} \mathrm{C}$ and (c) $200^{\circ} \mathrm{C}$ for $6 \mathrm{~h}$, (d) $180^{\circ} \mathrm{C}$ for $3 \mathrm{~h}$ and (e) $180{ }^{\circ} \mathrm{C}$ for $12 \mathrm{~h}$. The right figures show the size distribution of the corresponding left samples.

distributions (Fig. 3 right column) were obtained by counting the 100 particles taken from the TEM images. The average particle sizes of the $\mathrm{MgFe}_{2} \mathrm{O}_{4}$ nanoparticles synthesized for $6 \mathrm{~h}$ increased from $114.4 \mathrm{~nm}$ to $159.9 \mathrm{~nm}$ when the temperature increased from $160{ }^{\circ} \mathrm{C}$ to $200{ }^{\circ} \mathrm{C}$ (shown in Fig. 3a-c). The sample synthesized at $160{ }^{\circ} \mathrm{C}$ for $6 \mathrm{~h}$ have a standard deviation of $38.4 \mathrm{~nm}$, showing a wide size distribution and non-uniform. When the synthesis temperature increased to $200{ }^{\circ} \mathrm{C}$, the $\mathrm{MgFe}_{2} \mathrm{O}_{4}$ nanoparticles grew large, have a small standard deviation of $22.2 \mathrm{~nm}$ and became more uniform. Fig. 3b, d and e are TEM images of $\mathrm{MgFe}_{2} \mathrm{O}_{4}$ magnetic nanoparticles synthesized at $180^{\circ} \mathrm{C}$ for different times. From the results, we can see that the average particle sizes increased from $111.8 \mathrm{~nm}$ to $143.1 \mathrm{~nm}$, and then decreased to $114.3 \mathrm{~nm}$, the standard deviations increased from 17 to 24.7 and then decreased to 16.9 with the increase of reaction time. As we know, the particles grow with reaction time. So the average particle size increased when the reaction time increased from 3 hours to 6 hours. But, we also noted that the reaction was performed under strongly agitation that has the function of grinding. With the increase of reaction time, the agitation time also increased and the particle became small when the reaction time increased to 12 hours.

Fig. 4 shows the SEM images of $\mathrm{MgFe}_{2} \mathrm{O}_{4}$ magnetic nanoparticles and the EDS spectrum of the $\mathrm{MgFe}_{2} \mathrm{O}_{4}$ powders synthesized under different conditions. We can see that the particle sizes of the $\mathrm{MgFe}_{2} \mathrm{O}_{4}$ magnetic nanoparticles obtained at different reaction conditions are relatively uniform, which are consistent with the TEM analysis. The EDS spectrum images of $\mathrm{MgFe}_{2} \mathrm{O}_{4}$ magnetic nanoparticles show that the main elements of the synthesized $\mathrm{MgFe}_{2} \mathrm{O}_{4}$ powder are $\mathrm{Mg}$, Fe and $\mathrm{O}$, and no other impurity elements are found. To better analyze the composition of the constituent elements of $\mathrm{MgFe}_{2} \mathrm{O}_{4}$ magnetic nanoparticles, we calculated the atomic ratio of $\mathrm{Mg}$ and $\mathrm{Fe}$ elements. We found that the atomic ratio of $\mathrm{Mg}$ and $\mathrm{Fe}$ of the synthesized $\mathrm{MgFe}_{2} \mathrm{O}_{4}$ nanoparticles gradually increased from $1: 5.05$ to $1: 3.69$ when the reaction temperature increased from $160{ }^{\circ} \mathrm{C}$ to $200{ }^{\circ} \mathrm{C}$ and the reaction time was $6 \mathrm{~h}$ (Fig. $4 \mathrm{a}-\mathrm{c}$ ). When the synthesis temperature was $180{ }^{\circ} \mathrm{C}$, the atomic ratios of $\mathrm{Mg}$ and Fe decreased from $1: 2.34$ to $1: 4.53$ with the reaction time (Fig. 4b, d and e). Only the sample synthesized at $180^{\circ} \mathrm{C}$ for $3 \mathrm{~h}$ had an atomic ratio of $\mathrm{Mg}$ : Fe that is nearly $1: 2$. The Mg substitution in ferrite decreased with the reaction time increased or the reaction temperatures were lower or higher than $180^{\circ} \mathrm{C}$. As we all know, composition is one of the critical factors influencing the properties and performance of the synthesized $\mathrm{MgFe}_{2} \mathrm{O}_{4}$ magnetic nanoparticles.

In order to further analyze the relationship between the different reaction conditions and the magnetic properties of $\mathrm{MgFe}_{2} \mathrm{O}_{4}$ magnetic nanoparticles, the magnetic properties of the $\mathrm{MgFe}_{2} \mathrm{O}_{4}$ magnetic nanoparticles synthesized under different reaction conditions are shown in Fig. 5. From Fig. 5a, 

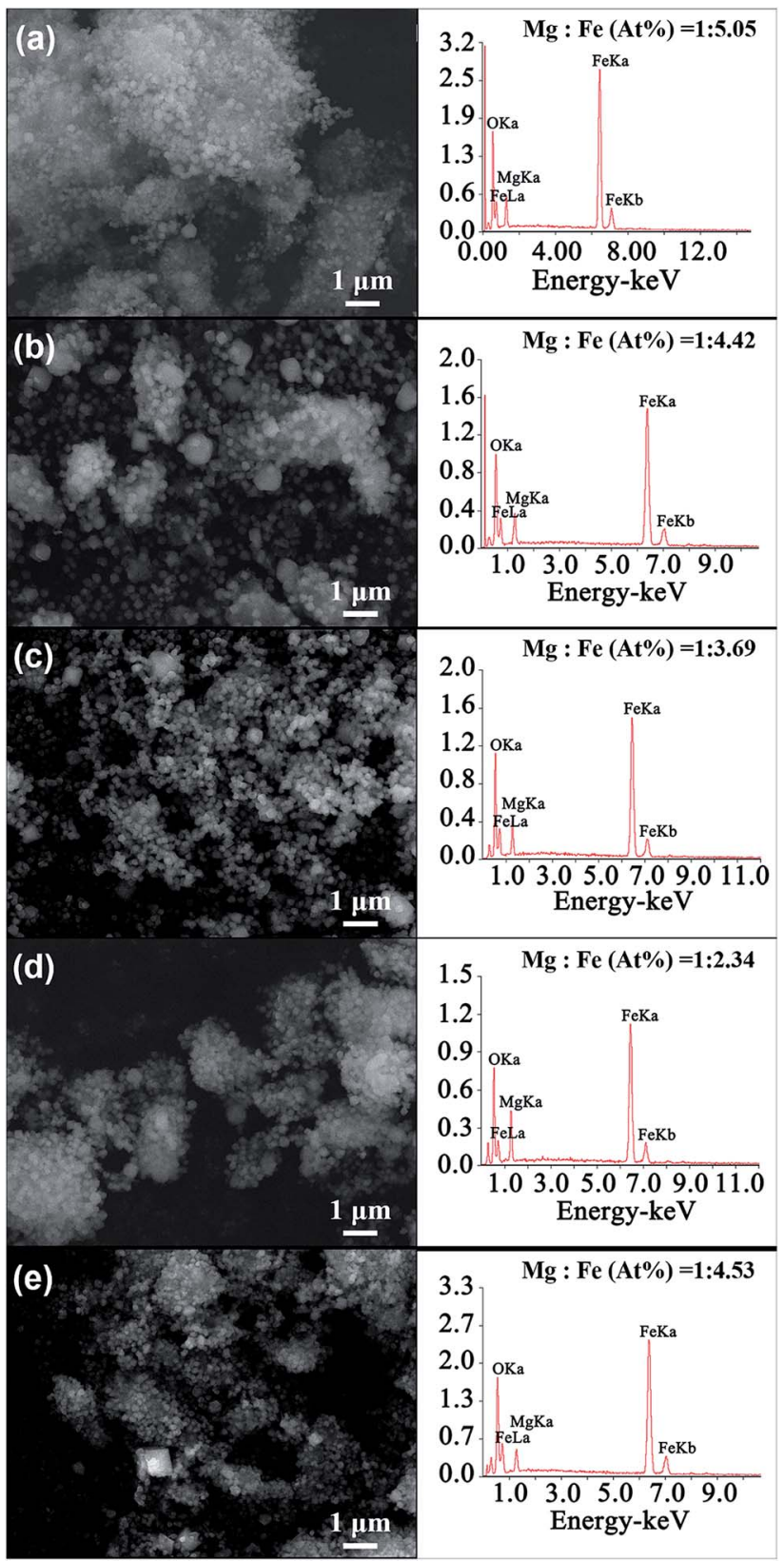

Fig. 4 SEM images of $\mathrm{MgFe}_{2} \mathrm{O}_{4}$ magnetic nanoparticles synthesized at (a) $160{ }^{\circ} \mathrm{C}$, (b) $180{ }^{\circ} \mathrm{C}$ and (c) $200{ }^{\circ} \mathrm{C}$ for $6 \mathrm{~h}$, (d) $180{ }^{\circ} \mathrm{C}$ for $3 \mathrm{~h}$ and (e) $180^{\circ} \mathrm{C}$ for $12 \mathrm{~h}$. The right figures show the EDS spectrum images of the corresponding left samples.

we can see that the saturation magnetizations are increased from $51.8 \mathrm{emu} \mathrm{g}^{-1}$ to $60.2 \mathrm{emu} \mathrm{g}^{-1}$ when the reaction temperature increased from $160^{\circ} \mathrm{C}$ to $200^{\circ} \mathrm{C}$ and reaction time was $6 \mathrm{~h}$. When the synthesis temperature was $180^{\circ} \mathrm{C}$, the saturation magnetizations of the $\mathrm{MgFe}_{2} \mathrm{O}_{4}$ nanoparticles gradually increased from $41.3 \mathrm{emu} \mathrm{g}^{-1}$ to $67.4 \mathrm{emu} \mathrm{g}^{-1}$ as the reaction time is prolonged from $3 \mathrm{~h}$ to $12 \mathrm{~h}$ (shown in Fig. $5 \mathrm{~b}$ ). Saturation magnetization is one of the important properties of the soft magnetic nanoparticles. Magnetic nanoparticles with excellent magnetic properties can be better and more widely used. ${ }^{24}$ For the synthesized $\mathrm{MgFe}_{2} \mathrm{O}_{4}$ magnetic nanoparticles, the
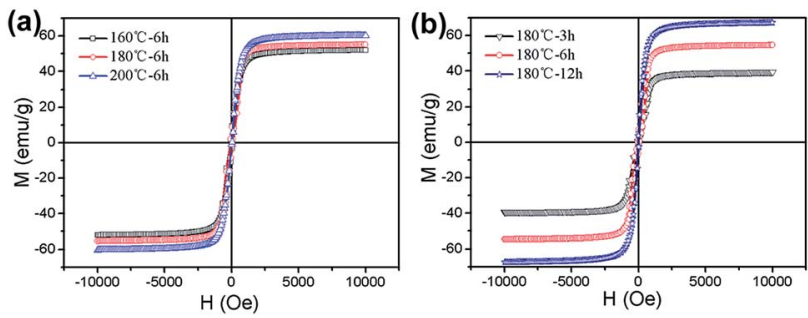

Fig. 5 Magnetization curves of $\mathrm{MgFe}_{2} \mathrm{O}_{4}$ nanoparticles synthesized (a) for $6 \mathrm{~h}$ at different temperatures, (b) at $180^{\circ} \mathrm{C}$ for different times.

saturation magnetization of the spinel magnesium ferrite nanoparticles obtained at $180{ }^{\circ} \mathrm{C}$ for 12 hours is as high as 67.4 emu $\mathrm{g}^{-1}$.

To explore the dependence of the morphology, composition and magnetic properties, we compare the particle size, $\mathrm{Mg}: \mathrm{Fe}$ ratio and saturation magnetization of the $\mathrm{MgFe}_{2} \mathrm{O}_{4}$ nanoparticles synthesized under different reaction conditions in Table 1. It can be seen intuitively that the average particle sizes of the samples gradually increased and became uniform with the reaction temperature when synthesis time was $6 \mathrm{~h}$, indicating that the reaction temperature have a certain influence on the particle size. From XRD analysis, when the reaction time is 6 hours, the intensity of the diffraction peak of the $\mathrm{MgFe}_{2} \mathrm{O}_{4}$ nanoparticles gradually increased as the reaction temperatures increased from $160^{\circ} \mathrm{C}$ to $200^{\circ} \mathrm{C}$ (shown in Fig. 2a). Therefore, as the reaction temperature increases, the nanoparticles grow and the intensities of the diffraction peak increase, contributing to an increase of the magnetic properties of the synthesized $\mathrm{MgFe}_{2} \mathrm{O}_{4}$ nanoparticles.

From Table 1, we can see that the amount of Fe element reduced as the reaction temperature increases when the reaction time was $6 \mathrm{~h}$ and increased with the reaction time when the temperature was fixed at $180^{\circ} \mathrm{C}$, but the change is not large. The sample synthesized at $180{ }^{\circ} \mathrm{C}$ for $3 \mathrm{~h}$ and with the lowest Fe amount obtained the lowest saturation magnetization, indicating that $\mathrm{Fe}$ amount is very important for the magnetic properties of $\mathrm{MgFe}_{2} \mathrm{O}_{4}$ nanoparticles. The sample synthesized at $180^{\circ} \mathrm{C}$ for $12 \mathrm{~h}$ got the highest saturation magnetization of 67.4 $\mathrm{emu}^{-1}$. This sample has a narrower size distribution than that of the sample synthesized at $160{ }^{\circ} \mathrm{C}$ for $6 \mathrm{~h}$ that had a similar average particle size and lower Fe amount. This result indicate that size distribution also has critical effect on the magnetic properties. Thus, there is a strong dependence between the particle size, composition, crystallization and magnetic properties and $\mathrm{MgFe}_{2} \mathrm{O}_{4}$ nanoparticles with narrow size distribution, good crystallinity, appropriate $\mathrm{Mg}: \mathrm{Fe}$ ratio has the highest saturation magnetization.

\section{Conclusions}

In summary, we synthesized monodispersed, single crystal magnesium ferrite nanoparticles by simple solvothermal method. We have found that the reaction time and temperature have an important influence on the particle size, size distribution, composition and magnetic properties of the synthesized 
$\mathrm{MgFe}_{2} \mathrm{O}_{4}$ nanoparticles and there is a strong dependence between the particle size, composition, crystallization and magnetic properties. The $\mathrm{MgFe}_{2} \mathrm{O}_{4}$ magnetic nanoparticles synthesized at $180{ }^{\circ} \mathrm{C}$ for 12 hours have excellent dispersion, rectangular shape, narrow particle size distribution and a saturation magnetization of $67.35 \mathrm{emu}^{-1}$. This work provides a convenient and good controlling synthesis method for the application of single crystal spinel magnesium ferrite nanoparticles.

\section{Conflicts of interest}

There are no conflicts to declare.

\section{Acknowledgements}

This work has been financially supported by the Natural Science Foundation of Hebei of China under No. E2017402039, No. E2017402139, the Education Department of Hebei of China under No. ZD2017014, the key research and development projects of Hebei of China under No. 18211904D. The authors also thanks for the support of the National 973 Project under Grants 2014CB643701.

\section{Notes and references}

1 D. Lisjak and A. Mertelj, Prog. Mater. Sci., 2018, 95, 286.

2 J. Nonkumwong, P. Pakawanit, A. Wipatanawin, P. Jantaratana, S. Ananta and L. Srisombat, Mater. Sci. Eng., C, 2016, 61, 123.

3 G. Wang, Y. Ma, M. Li, G. Cui, H. Che, J. Mu, X. Zhang, Y. Tong and X. Dong, Solid State Sci., 2017, 63, 70.

4 Y. L. Liu, Z. M. Liu, Y. Yang, H. F. Yang, G. L. Shen and R. Q. Yu, Sens. Actuators, B, 2005, 107, 600.

5 H. G. Kim, P. H. Borse, J. S. Jang, E. D. Jeong, O. S. Jung and Y. J. Suhd, Chem. Commun., 2009, 58, 89.
6 Y. Pan, Y. Zhang, X. Wei, C. Yuan, J. Yin, D. Cao and G. Wang, $\mathrm{MgFe}_{2} \mathrm{O}_{4}$ nanoparticles as anode materials for lithium-ion batteries, Electrochim. Acta, 2013, 109, 89.

7 L. Zhao, X. Li, Q. Zhao, Z. Qu, D. Yuan, S. Liu, X. Hu and G. Chen, J. Hazard. Mater., 2010, 184, 7049.

8 V. Šepelák, D. Baabe, D. Mienert, F. J. Litterst and K. D. Becker, Scr. Mater., 2003, 48, 961.

9 Q. Chen and Z. J. Zhang, Appl. Phys. Lett., 1998, 73, 3156.

10 M. P. Pileni, Nat. Mater., 2003, 2, 145.

11 K. K. Bamzai, G. Kour, B. Kaur and S. D. Kulkarni, J. Magn. Magn. Mater., 2013, 327, 159.

12 Z. Bazhan, F. E. Ghodsi and J. Mazloom, Electrochim. Acta, 2017, 250, 143.

13 Q. A. Pankhurst, J. Connolly and S. K. Jones, J. Phys. D: Appl. Phys., 2003, 36, R167.

14 C. Li, X. Han and F. Cheng, Nat. Commun., 2015, 6, 7345.

15 Y. Huang, Y. Tang and J. Wang, Mater. Chem. Phys., 2006, 97, 394.

16 Y. Shen, Y. Wu and X. Li, Mater. Lett., 2013, 96, 85.

17 N. Sivakumar, A. Narayanasamy, J. M. Greneche, R. Murugaraj and Y. S. Lee, J. Alloys Compd., 2010, 504, 395. 18 V. Šepelák, A. Feldhoff, P. Heitjans, F. Krumeich, D. Menzel, F. J. Litterst, I. Bergmann and K. D. Becker, Chem. Mater., 2006, 18, 3057.

19 S. K. Durrani, S. Naz, M. Mehmood, M. Nadeem and M. Siddique, J. Saudi Chem. Soc., 2017, 21, 899.

20 P. P. Hankare, S. D. Jadhav, U. B. Sankpal, R. P. Patil, R. Sasikala and I. S. Mulla, J. Alloys Compd., 2009, 488, 270.

21 D. Chen, D. Li, Y. Zhang and Z. Kang, Ultrason. Sonochem., 2013, 20, 1337.

22 T. Sasaki, S. Ohara, T. Naka, J. Vejpravova, V. Sechovsky, M. Umetsu, S. Takami, B. Jeyadevan and T. Adschiri, J. Supercrit. Fluids, 2010, 53, 92.

23 M. Sivakumar, V. Umapathy and R. S. Babu, J. Supercond. Novel Magn., 2013, 26, 725.

24 M. A. Gonzalez-Fernandez, T. E. Torres and M. AndrésVergés, J. Solid State Chem., 2009, 182, 2779. 